\title{
SELEÇÃO DOS AGRICULTORES PARA USO DE INOVAÇÕES TECNOLÓGICAS DE PRODUÇÃO
}

\author{
Diony Alves Reis ${ }^{1}$; Andréa Hentz de Mello \\ ${ }^{1}$ Engenheiro Agrônomo, Bolsista FAPESPA. E-mail: dionyodin@gmail.com \\ ${ }^{2}$ Prof. ${ }^{\text {a }, ~ D . S c ., ~ F C A M . ~ E-m a i l: ~ a n d r e a h e n t z @ u f p a . b r ~}$
}

RESUMO: O solo é um componente fundamental para o desenvolvimento dos sistemas agrícolas e dependendo do manejo empregado obtém-se o sucesso ou o fracasso das atividades produtivas. A adoção de práticas convencionais de exploração tem levado os solos à degradação e consequentemente ao abandono, gerando entraves ao desenvolvimento produtivo regional. Nesse sentido, discutir novas alternativas tecnológicas que não coloquem em risco as bases dos sistemas produtivos é de fundamental importância, possibilitando a utilização de práticas ecologicamente sustentáveis. A utilização de Fungos Micorrízicos Arbusculares (FMA's) merece atenção especial pelos benefícios em muitas espécies de plantas em condições de estresse, com destaque aos de natureza nutricional, especialmente de P (fósforo). A diversidade de FMA's pode ser um fator determinante da produtividade e diversidade de plantas em um dado ecossistema ao mesmo tempo em que a planta exerce influência quantitativa e qualitativa na ocorrência desses fungos. Nesse contexto, este trabalho tem o objetivo de identificar agricultores familiares, em áreas de assentamentos, interessados em utilizar inóculos de FMA's para incremento inicial de sistemas sgroflorestais. A seleção dos agricultores se dará através de visitas por um técnico participante do Projeto, que se responsabilizará por reunir os agricultores, apresentar-lhes o projeto, seus idealizadores, a metodologia, os objetivos e os resultados esperados. Os agricultores interessados pela tecnologia poderão ser beneficiários do projeto, bastando apenas que se comprometam a fornecer as sementes das culturas que lhe interessam e acompanharem o desenvolvimento das mudas no campo. A produção dos fungos micorrízicos arbusculares e das mudas será realizado na casa de vegetação da Universidade Federal do Pará, no campus Universitário de Marabá, no Assentamento Agrícolas Palmares, no Município de Parauapebas - PA e no Assentamento 26 de Março, em Marabá - PA. O procedimento de extração de esporos de FMA's do solo será feito a partir de uma amostra de solo, composta de 10 sub-amostras coletadas na profundidade de $0-20$ $\mathrm{cm}$. Desta amostra composta de solo, será retirada uma amostra de $50 \mathrm{~g}$, a partir da qual será realizada a contagem dos esporos. Em seguida, os esporos, serão preparados em laminas e identificados segundo suas características morfológicas. Outra parte do solo será utilizada para identificação indireta dos FMA's, onde irá ser instalado em casa de vegetação, um cultivo armadilha com Brachiaria brizantha com o objetivo de recuperação das espécies de fungos, que não estavam esporulados no momento da coleta. As unidades experimentais serão vasos de $1000 \mathrm{~g}$ de capacidade, nos quais será feita a semeadura com Brachiaria brizantha, utilizando-se uma alta densidade de semeadura, visando forçar o desenvolvimento do sistema radicular. Em seguida, serão distribuídos o inóculos de fungos micorrízicos de diversas espécies para os agricultores interessados na produção das mudas. É esperado que os agricultores selecionados percebam a importância dos fungos micorrízicos no processo de produção das mudas e melhoria das propriedades morfológicas do solo e que, além disso, sejam multiplicadores da idéia formando um grande grupo de usuários dessa tecnologia. O presente trabalho será realizado com o apoio da FAPESPA - Fundação de Amparo a Pesquisa do Estado do Pará.

PALAVRAS-CHAVE: Sustentabilidade, organismos, biodiversidade. 